International Journal of Advanced Trends in Computer Science and Engineering Available Online at http://www.warse.org/IJATCSE/static/pdf/file/ijatcse4481.52019.pdf

https://doi.org/10.30534/ijatcse/2019/4481.52019

\title{
Exploring the Moderating Effect of Technology Readiness of User Intention in the Context of Mobile Payment Service
}

\author{
${ }^{1}$ Husni Teja Sukmana, ${ }^{2}$ Taqwa Hariguna, ${ }^{3}$ Ninda Lutfiani, ${ }^{4}$ Untung Rahardja \\ ${ }^{1}$ Department Informatics, Universitas Syarif Hidayatullah, Indonesia \\ ${ }^{2}$ Department Information System, Universitas Amikom Purwokerto, Indonesia \\ ${ }^{3,4}$ Master program Information Technology, University of Raharja, Indonesia
}

\begin{abstract}
Mobile technology is becoming increasingly high in use in everyday life today. At present, mobile payment is also a trend in society as one of the impacts of the high use of internet and mobile technology. However, from the aspect there is a lack of service acceptance in the mobile payment model among customers. The method used in this study is the unified theory of acceptance and use of technology and technology readiness (TR). The proposed framework identifies several factors that underlie user intentions to use mobile payment. This framework is tested on m-payment users with two mobile payment startup platforms OVO and Go Pay in Indonesia. The conceptual model developed and tested in this study focuses on the factors that determine consumer acceptance of mobile payment services. Empirical results show strong support for the effect of Performance expectancy, Effort expectancy, Social influence and Facilitating conditions on use intention in mobile payment applications. Our study offers several implications for managers in terms of marketing mobile payment solutions to increase consumer intention to use this service.
\end{abstract}

Key words: Mobile payment, UTAUT, TR

\section{INTRODUCTION}

The trend of increasing smartphone penetration in Indonesia and people without cash has great potential to develop mobile or digital-based payment systems. At present, the cellular payment market in Indonesia is increasingly crowded because companies are in a hurry to take advantage of populations that do not have bank accounts and they offer practicality and convenience for users. Even today most banks have used digital technology as part of the company's strategy. This digital bank application allows people to carry out financial activities, such as saving and transferring money via smartphones.

Payment system financial technology (fintech) services are now also developing in Indonesia. There are two giant players like GoPay and OVO who now control the market in Indonesia. These two services are favored by people who want convenience in making payment transactions.

In Indonesia itself the circulation of cash is also very high, but now the population of Indonesia has also begun to use server-based electronic money to replace cash. However, debit and credit cards also still show growth. Currently OVO and GoPay are still heavily used in Java. Smartphones in Indonesia are currently much faster than the number of bank accounts. So making server-based electronic money growth can be very fast. The use of digital services continues to grow because Indonesia still has great potential to become an arena of collaboration between banks and fintech services. This shows that competition between traditional banks and digital services is getting tougher. Therefore, banks must also get ready and use new strategies to maintain and hook the interests of new customers to continue using traditional bank services.

This observation leads to the question why consumers adopt the mobile payment service. Previous research has provided a rather limited understanding of the main drivers of consumer acceptance of mobile payment services. A comprehensive study of these factors offers the potential to gain important managerial implications on how mobile payment services can be marketed more effectively, thus leading to greater consumer acceptance. This is important because the number of companies that have offered or are interested in adopting mobile payment options has increased, and guidance is needed on how managers can effectively 
Husni Teja Sukmana et al., International Journal of Advanced Trends in Computer Science and Engineering, 8(1.5), 2019, 249 - 257

increase the number of customers who choose this form of payment as an alternative to traditional payment service models. Given the high practical relevance and scarcity of previous empirical research, this study aims to develop and test an integrative model of factors that determine consumer acceptance of mobile payment services. For this purpose, we collected data from a representative sample of 457 respondents and used Smart PLS software and SEM equation modeling to test research models based on mobile payment acceptance theory. Our results reveal a major driver of consumer intention to use mobile payment services. Among the main drivers is effort expectancy, which is the extent to which mobile payments can be reconciled with values that exist in society. In addition, performance expectancy also contributes, namely facilitating conditions, and social influence, namely the perception of the social environment on mobile payment.

This article has two main contributions. From a conceptual point of view, we develop models based on various theoretical fields that are relevant to consumers' motives for using mobile payment solutions. This allows us to describe a broader and more holistic picture of the drivers of consumer acceptance of mobile payment services compared to previous research. From an empirical point of view, we make a contribution by testing this model with a large sample, which allows us to carry out several stability tests to increase confidence in the findings. Providing reliable evidence and confirmation about the relevance of various acceptance factors is very important because previous research on mobile payments is basically qualitative in nature.

The outline of this research is as follows: First, we define the key terms used in our research and outline theoretically the unified theory of acceptance and use of technology (UTAUT), which provides a general structure for our research model. Next, we review our previous work on receiving mobile payments. Building on theories and extant knowledge about the phenomenon of consumer acceptance, we present our hypothesis, establishing a set of proposed factors to directly or indirectly determine consumers' intention to use a mobile payment solution. In the method section, we describe the survey and discuss the validity and reliability of empirical data. We then present our substantive results and check our stability. This paper concludes with a summary of the main findings and discussion of the research implications.

\section{LITERATURE REVIEW}

\subsection{Mobile payment theory}

Mobile payment services can be considered as a special form of handling electronic payments. Looking at the definitions available, we found several different similarities and differences. Most conceptualizations emphasize cellular devices as the main characteristic that distinguishes cellular payments from other forms of payment. Some authors focus on cell phones [1], while others include all cellular communication devices [2]. Regarding the mobile payment function, all definitions refer to monetary value transfers. Differences can be found when it comes to the payment processing phase which is considered part of mobile payment. [1], for example, refers to the authorization and initiation of the payment process in its definition, and [3] also include this realization, namely the implementation of payments, in their definition. In this study, we adopt a broad view of mobile payment services and examine all payments for goods, services, and bills that are authorized, initiated, or realized with a mobile device. In this research we focus on consumers as users of mobile payment services.

Reviewing the relevant literature, we find that only a basic understanding exists about the drivers of mobile payment acceptance. There are three groups of researchers who have published empirical work on this topic. In a survey-based study, [4] asked consumers what characteristics of mobile payment applications they considered relevant. The authors presented a frequency analysis, showing that consumers preferred payment services that were simple, safe, and inexpensive.

Zmijewska, Lawrence, and Steele developed a useroriented taxonomy of the mobile payment system [2], [5], [6]. They classified existing mobile payment systems, evaluated them based on a set of consumeroriented criteria. The relevant classification dimensions included factors such as simplicity, safety, and cost. However, an examination of the dimensions was not included.

Dahlberg, Mallat, and Öörni explained [7], [8]. Based on group interviews, they analyzed the factors that contributed to the acceptance of the cellular payment system. Their empirical study included consumers in various age groups and from different professional backgrounds. The participants' comments during the next open discussion were coded by the researchers, producing three relevant factors related to acceptance via mobile payment: perceived ease of use, perceived 
Husni Teja Sukmana et al., International Journal of Advanced Trends in Computer Science and Engineering, 8(1.5), 2019, 249 - 257

usefulness, and trust. The results were interpreted as confirming the general application of the technology acceptance model in the context of mobile payment services. However, given the nature of the data, no confirmation test of this proposition was used. Therefore, the authors called for future research to verify their exploration findings [7].

\subsection{The unified theory of acceptance and use of technology}

While these theories regarding the adoption of IT / IS exist independently of one another, their construction has the potential to overlap [9]. Other researchers see existing models as limited by the strength of their predictions and suggest making empirical comparisons or extensions of existing models as a way to improve understanding of consumer behavior [10], [11] proposed UTAUT based on conceptual similarities from the previous model. UTAUT contains four core determinants of intention and use: performance expectations (PE), business expectations (EE), social influence (SI) and facilitating conditions (FC). PE is defined as the extent to which an individual believes the system will benefit performance on a job [12]. This construct is derived from previous theories including TAM and DTPB which describe perceptions of usefulness, motivational models or in other words extrinsic motivation), then PC utilization models (MPCU) or job-fit), then there are diffusion theories that explain relative advantages and social cognitive theories that describe the theory of outcome expectations. EE reflects the level of ease associated with using the system [12]. As such, it resembles the construct of perceived ease of use as explained in TAM, diffusion theory, and MPCU. Social influence is defined as "the extent to which a person feels that the other person believes that he has used a new system" [12]. It integrates aspects of subjective norms (TRA, TPB, combined-TAM-TPB (C-TAM-TPB)), social factors (MPCU). Finally, FC illustrates the importance of individuals attached to the existence of organizational infrastructure and can technically support the use of the system [12]. This construct can also be found at MPCU and is related to the concept of perceived behavioral control (TPB / DTPB, C-TAM-TPB) and compatibility (diffusion of innovation theories). The UTAUT framework further estimates a number of user-specific factors that moderate the impact of core predictors on usage intentions and usage behavior. Therefore, depending on gender, age, level of experience and voluntary use, the impact of antecedent factors on intention to use and usage behavior will be stronger or weaker. The UTAUT framework has been used to predict the acceptance of various technology products and services [13], [14], [15], [16], [17]. Based on the above considerations, consumer acceptance of mobile payment is expected to be subject to the same reason, it is hypothesized that:

H1. PE is positively related to customer intention to use mobile payments.

$\mathrm{H} 2$. EE is positively related to customer intention to use mobile payments.

H3. SI is positively related to customer intention to use mobile payments.

$\mathrm{H} 4$. FC is positively related to customer intention to use mobile payments.

\subsection{Technology readiness}

While most acceptance frameworks focus on instrumental cognitive determinants and SI, the specific nature of users also plays a role in shaping the level of acceptance [18], [19], [20], [21], [22] explains that TR represents one of these personality traits. TR is defined as an individual's tendency to embrace and use new technology to achieve goals in everyday life. It is used to measure a person's general state of mind about technology, and does not measure in terms of one's expertise or level of experience in using technology. The construction consists of four dimensions. Optimism reflects an individual's positive view of technology based on the belief that technology makes life more efficient, flexible, and controlled [23]. Innovative skills are related to one's tendency to become a technology pioneer and assume thought leadership. Discomfort expresses a person's feelings flooded with technology. Insecurity is rooted in the belief that technology will not function properly. While optimism and innovation are two things that drive a person's TR, discomfort and insecurity contain the opposite. A number of studies have analyzed the role of TR in relation to consumer intentions to use technology [24], [25], [26], [27], [28].

It can be concluded from the formulation above that consumers' willingness to use mobile payments is formed by the elements of usability and individual user characteristics. While individual traits have largely been formulated as antecedents for the use of technology, their moderation effect on the relationship between system perception and system use has so far received little attention and therefore needs further research [29]. Therefore, it is hypothesized that:

H1.1. TR moderates the impact of PE on consumer's intention to use mobile payments.

H2.1. TR moderates the impact of EE on consumer's intention to use mobile payments.

H3.1. TR moderates the impact of SI on consumer's intention to use mobile payments. 
Husni Teja Sukmana et al., International Journal of Advanced Trends in Computer Science and Engineering, 8(1.5), 2019, 249 - 257

H4.1. TR moderates the impact of FC on consumer's intention to use mobile payments.

The overall framework, as shown in Figure 1, is a synthesis of the basic UTAUT model and the TR construct. Because this research involves mobile payment users, the measurement in terms of mobile payment usage is limited to the analysis of consumer use intentions. This study uses a classification scheme consisting of early adopters, which consists of actual users of mobile payment when consumers use mobile payment services, and potential adopters. Potential adopters indicate their intended use with respect to first time use. In the case of early adopters, intention refers to a continuation intention. Furthermore, the original set of user demographics in the UTAUT model is omitted, due to extensive prior research. Instead, TR is integrated into the framework. Overall, the research framework is set to explore how antecedents to changes in the use of mobile payment as new technology develop from the initial adoption stage for market penetration.

\section{RESEARCH METHODOLOGY}

\section{Construct measurement and questionnaire design}

The study population consisted of the general public of mobile payment service users in Indonesia, specifically the OVO and Go Pay applications. The information needed for this study was not available in the form of secondary data, so we collected primary data through surveys. The survey was conducted using a standard online questionnaire, which was subjected to comprehensive pretesting before implementation. At the end of the data collection period, 457 acceptable responses were received.

.The measurement items were formulated as Likerttype-anchored statements on a seven-point scale, ranging from 1 ("strongly disagree") to 7 ("strongly agree").

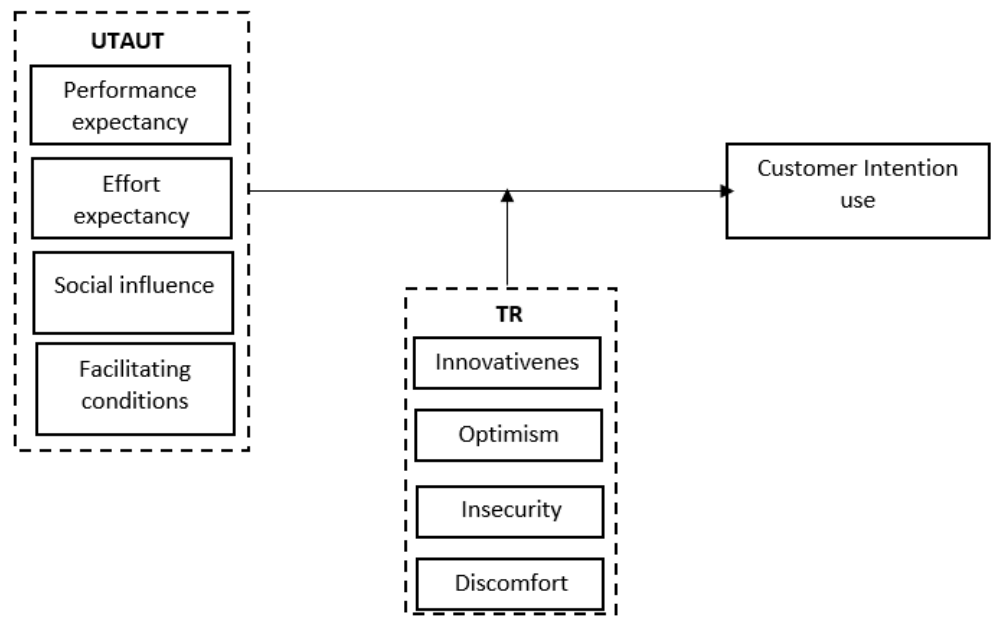

Figure 1: Research framework

\section{DATA ANALYSIS}

Partial least square (PLS) research models were used to verify the model's stability and hypothesis testing. SmartPLS 2.0 software was used to conduct PLS analysis [31][32]. PLS is a structural equation modeling (SEM) technique based on analytical analysis and regression. PLS was used here as an analytical method for the following reasons. First, an integrated model will be developed to test consumer CIs for mobile payment activities. A number of constructions were considered in this framework, such as PE, EE, SI, FC CI and TR. Second, the TR observed in this research was the construct of the second-order formative measurement so that PLS can be used to simultaneously process reflective and formative indicators. However, because PLS did not test significance, the re-sampling procedure was used for significance testing. In this context, this study used the bootstrap method, which repeatedly took and returned samples used to simulate random sample sizes. Appropriate simulation samples were then used to carry out statistical evaluations and tests. Based on the suggestions proposed by [33][34], the number of repeat samples was set to be 1000 to achieve a stable parameter estimate.

Factor loads and the results of the reliability tests of various construction items are described in Table 1. Cronbach's $\alpha$ value and the composite reliability of all constructs was 0.7 or higher, indicating that the construct was reliable. 
Table 1: Reliability analysis and convergent validity

\begin{tabular}{|c|c|c|c|c|c|c|c|}
\hline Construct & $\begin{array}{l}\text { Measurement } \\
\text { Items }\end{array}$ & $\begin{array}{l}\text { Factor } \\
\text { loading/ } \\
\text { coefficient } \\
\text { (t-value) }\end{array}$ & AVE & $\begin{array}{l}\text { Composite } \\
\text { Reliability }\end{array}$ & $\begin{array}{l}\mathbf{R} \\
\text { Square }\end{array}$ & $\begin{array}{l}\text { Cronbachs } \\
\text { Alpha }\end{array}$ & Communality \\
\hline \multirow{3}{*}{$\begin{array}{l}\text { Customer } \\
\text { Intention use } \\
\text { (CI) }\end{array}$} & CI1 & 0.97 & \multirow{3}{*}{0.87} & \multirow{3}{*}{0.95} & \multirow{3}{*}{0.94} & \multirow{3}{*}{0.92} & \multirow{3}{*}{0.87} \\
\hline & CI2 & 0.85 & & & & & \\
\hline & $\mathrm{CI} 3$ & 0.97 & & & & & \\
\hline \multirow{3}{*}{$\begin{array}{l}\text { Effort } \\
\text { expectancy } \\
\text { (EE) }\end{array}$} & EE1 & 0.93 & \multirow{3}{*}{0.79} & \multirow{3}{*}{0.92} & & \multirow{3}{*}{0.87} & \multirow{3}{*}{0.79} \\
\hline & EE2 & 0.81 & & & & & \\
\hline & EE3 & 0.92 & & & & & \\
\hline \multirow{3}{*}{$\begin{array}{l}\text { Facilitating } \\
\text { conditions } \\
\text { (FC) }\end{array}$} & FC1 & 0.93 & \multirow{3}{*}{0.79} & \multirow{3}{*}{0.92} & & \multirow{3}{*}{0.87} & \multirow{3}{*}{0.79} \\
\hline & FC2 & 0.93 & & & & & \\
\hline & FC3 & 0.80 & & & & & \\
\hline \multirow{3}{*}{$\begin{array}{l}\text { Performance } \\
\text { expectancy } \\
\text { (PE) }\end{array}$} & PE1 & 0.93 & \multirow{3}{*}{0.77} & \multirow{3}{*}{0.91} & & \multirow{3}{*}{0.86} & \multirow{3}{*}{0.77} \\
\hline & PE2 & 0.78 & & & & & \\
\hline & PE3 & 0.93 & & & & & \\
\hline \multirow{3}{*}{$\begin{array}{l}\text { Social } \\
\text { influence (SI) }\end{array}$} & SI1 & 0.91 & \multirow{3}{*}{0.81} & \multirow{3}{*}{0.93} & & \multirow{3}{*}{0.88} & \multirow{3}{*}{0.81} \\
\hline & SI2 & 0.90 & & & & & \\
\hline & SI3 & 0.89 & & & & & \\
\hline \multirow{3}{*}{$\begin{array}{l}\text { Insecurity } \\
\text { (INS) }\end{array}$} & INS1 & 0.93 & \multirow{3}{*}{0.84} & \multirow{3}{*}{0.94} & & \multirow{3}{*}{0.91} & \multirow{3}{*}{0.84} \\
\hline & INS2 & 0.87 & & & & & \\
\hline & INS3 & 0.95 & & & & & \\
\hline & INV1 & 0.80 & & & & & \\
\hline $\begin{array}{l}\text { Innovativeness } \\
\text { (INV) }\end{array}$ & INV2 & 0.92 & 0.78 & 0.91 & & 0.85 & 0.78 \\
\hline & INV3 & 0.91 & & & & & \\
\hline & OPT1 & 0.92 & & & & & \\
\hline Optimism & OPT2 & 0.95 & 0.88 & 0.96 & & 0.93 & 0.88 \\
\hline (OPT) & OPT3 & 0.95 & & & & & \\
\hline & DCT1 & 0.86 & & & & & \\
\hline Discomfort & DCT2 & 0.93 & 0.80 & 0.92 & & 0.88 & 0.80 \\
\hline & DCT3 & 0.90 & & & & & \\
\hline
\end{tabular}

To test construct validity, the tests were carried out namely convergent validity test and the discriminant validity. Based on the theory of [30] that a construct is declared valid if the load of indicator factors is greater than 0.5 , the average variance extracted (AVE) is greater than 0.5 , and the reliability is greater than 0.7. Table 2 shows that all constructs are in accordance with the concept proposed by [30], so this shows that convergent validity has been declared. In addition, the square root of AVE is greater than the construct correlation coefficient tested. Based on Table 1 and Table 2, the construction shows discriminant validity. 
Table 2: Correlation matrix

\begin{tabular}{|l|l|l|l|l|l|l|}
\hline & CI & EE & FC & PE & SI & TR \\
\hline CI & 0.93 & & & & & \\
\hline EE & 0.74 & 0.89 & & & & \\
\hline FC & 0.82 & 0.83 & 0.89 & & & \\
\hline PE & 0.76 & 0.85 & 0.84 & 0.88 & & \\
\hline SI & 0.88 & 0.83 & 0.81 & 0.89 & 0.90 & \\
\hline TR & 0.76 & 0.77 & 0.81 & 0.79 & 0.81 & 0.84 \\
\hline
\end{tabular}

To test the hypothesis accepted or rejected can be measured from the t-value, if t-value> 1.90 then the hypothesis is accepted and vice versa. The results of testing the hypotheses for the model are explained in
Table 3. Of the 4 existing hypotheses, 2 were accepted, namely EE-CI and FC-CI, while PE-CI and SI-CI were declared rejected.

Table 3: Summary of hypotheses testing results.

\begin{tabular}{|l|l|l|l|}
\hline Hypothesis & Path & t-value & results \\
\hline H1 & PE -> CI & 0.46 & No \\
\hline H2 & EE -> CI & 2.88 & Supported \\
\hline H3 & SI -> CI & 1.12 & No \\
\hline H4 & FC -> CI & 2.98 & Supported \\
\hline H1.1 & TR * PE -> CI & 0.97 & No \\
\hline H2.1 & TR * EE -> CI & 2.91 & Supported \\
\hline H3.1 & TR * SI -> CI & 0.61 & No \\
\hline H4.1 & TR * FC -> CI & 1.99 & Supported \\
\hline
\end{tabular}

\section{DISCUSSION}

\subsection{Academic contribution and future research}

This study is among the first to examine the determinants of consumer acceptance of mobile payment services in Indonesia. Based on theoretical considerations, we obtained a research model that sets the main driver of individual intentions to use mobile payment. Using data from large-scale surveys conducted in Indonesia, we found empirical support for the proposed model.

We found that perceived performance expectancy has the biggest impact on intention to use mobile payment services. So, to consider adopting a mobile payment service, people must find they can be reconciled with existing behavior patterns[35]. This is an important finding, because perceived performance expectancy is not part of the original TAM and as such is often not considered by acceptance researchers. The same is true for the second ranking factor. Facilitating conditions are the main driver for receiving cellular payments. One can interpret this finding as showing that, with an increasingly mobile society, mobile payment services are likely to gain significance in the future.

This study is intended as a valuable source for further empirical and conceptual research on mobile payment services. In addition to general contributions to identify, conceptualize, and operationalize the relevant revenue drivers of the mobile payment system, the results presented in this study produce further starting points for future investigations. This study focuses on the general acceptance of mobile payment services. We deliberately chose not to explore or classify mobile payment solutions.

As such, ongoing research work can be built on the structural model presented here and modify it to fit a particular payment solution. Furthermore, our empirical study is limited to samples in Indonesia. It will be useful to test whether the results persist in other countries. Thus, global generalizations from the results presented here can be tested and / or cultural 
differences that are important for the process of adopting mobile payments can be explored.

\subsection{Managerial implications}

While this study has a confirmation orientation and the main objective is not to obtain instrumental policy recommendations, some managerial implications can be drawn. What is very important for company managers who provide mobile payment solutions or offer them as a means of payment to customers is the question of how to effectively increase the number of users. The five factors summarized in Figure 1 can serve as a guideline to further increase market penetration of the mobile payment service.

Apparently, a very important managerial task is related to the perception of performance expectancy for mobile payment services. As such, industry players are challenged to develop and advertise mobile payment devices and solutions in ways that consumers deem appropriate to individual behavior patterns and prior experiences. In addition to perceptions of performance expectancy, facilitating conditions are the main driver of consumer acceptance of mobile payment services. Although these consumer characteristics cannot be influenced by the company, our findings can help managers in segmenting and prioritizing potential customers. In the early stages of the market today, companies must focus on consumers who have a strong need to pay for goods and services in every life situation, because they are more likely to be interested in mobile payment services. If this group of people can be inspired to use such services, the effects of discomfort and insecurity can make cellular consumers less interested in these services later on. Likewise, innovative and optimism are the main drivers of consumer acceptance that cannot be changed by management. However, it can be implied that reference groups play an important role in the diffusion of mobile payments. As such, companies need to identify initial users and stimulate the use of their mobile payment services, so that they can serve as a reference that facilitates broad diffusion in the future. Another interesting insight from management can be obtained from the relevance of security perception of cellular payment solutions. While we found a positive relationship of this factor with acceptance, the relationship was not as strong as expected because of the growing importance of the perceived risk construct in consumer research. This implies that risk-related concerns may not be center stage when launching a mobile payment service.
Conversely, managers need to focus on long-term strategic aspects to be highlighted to make mobile payment services that are used massively.

\section{REFERENCES}

1. Henkel, J. Mobile payment. In G. Silberer, J. Wohlfahrt, and T. Wilhelm (eds.), Mobile Commerce, Gabler, Wiesbaden, 2002. https://doi.org/10.1007/978-3-322-90464-5_18

2. Zmijewska, A., and Lawrence, E. Implementation models in mobile payment, In Proceedings of the IASTED International Conference, Puerto Vallarta, 2006, 19- 25.

3. Dahlberg, T., Mallat, N., Ondrus, J., and Zmijewska, A. Past, present and future of mobile payments research: a literature review. Electronic Commerce Research and Applications, 7, 2, 2008, 165-181.

https://doi.org/10.1016/j.elerap.2007.02.001

4. Linck, K., Pousttchi, K. and Wiedemann, D.G. Security issues in mobile payment from the customer viewpoint, In Proceedings of the 14th European Confer-ence on Information Systems (ECIS 2006), Göteborg, 2006.

5. Zmijewska, A., Lawrence, E. and Steele, R. Classifying m-payments, Paper Presented at the third International Conference on Mobile Business, New York, 2004

6. [Zmijewska, A., Lawrence, E. and Steele, R. Towards understanding of factors influencing user acceptance of mobile payment system, Paper Presented at the IADIS International Conference WWW/Internet, Madrid, 2004.

7. Dahlberg, T., Mallat, N. and Öörni, A. Consumer acceptance of mobile payment solutions. In G.M. Giaglis (ed.), mBusiness 2003 - The Second International Conference on Mobile Business, Vienna, 2003, 211-218.

8. Mallat, N. Theoretical constructs of mobile payment adoption. Paper Presented at the 27th Information Systems Research Seminar in Scandinavia (IRIS), Falkenberg, 2004.

9. Dillon, A. and Morris, M.G. (1996), "User acceptance of information technology: theories and models", Annual Review of Information Science and Technology, Vol. 31, pp. 3-32.

10. Stern, B.B., Royne, M.B., Stafford, T.F. and Bienstock, C.C. (2008), "Consumer acceptance of online auctions: an extension and revision of the TAM", Psychology \& Marketing, Vol. 25 No. 7, pp. 619-36. https://doi.org/10.1002/mar.20228

11. Kulviwat, S., Bruner, G.C. II, Kumar, A., Nasco, S.A. and Clark, T. (2007), "Toward a unified theory of consumer acceptance 
technology”, Psychology \& Marketing, Vol. 24 No. 12, pp. 1059-84.

12. Venkatesh, V., Moris, M., Davis, G. and Davis, F. (2003), "User acceptance of information technology: toward a unified view", MIS Quarterly, Vol. 27 No. 3, pp. 425-78.

13. Lin, C.-P. and Bhattacherjee, A. (2008), "Learning online social support: an investigation of network information technology based on UTAUT", CyberPsychology \& Behavior, Vol. 11 No. 3, pp. 268-72.

14. Wang, Y.-S. and Shih, Y.-W. (2009), "Why do people use information kiosks? A validation of the unified theory of acceptance and use of technology", Government Information Quarterly, Vol. 26 No. 1, pp. 158-65.

15. AbuShanab, E. and Pearson, J.M. (2007), "Internet banking in Jordan: the unified theory of acceptance and use of technology (UTAUT) perspective", Journal of Systems and Information Technology, Vol. 9 No. 1, pp. 7897.

https://doi.org/10.1108/13287260710817700

16. Al-Gahtani, S.S., Hubona, G.S. and Wang, J. (2007), "Information technology (IT) in Saudi Arabia: culture and the acceptance and use of IT", Information \& Management, Vol. 44, pp. 681-91.

17. Park, J.K., Yang, S.J. and Lehto, X. (2007), "Adoption of mobile technologies for Chinese consumers", Journal of Electronic Commerce Research, Vol. 8 No. 3, pp. 196-206.

18. Dabholkar, P. and Bagozzi, R.P. (2002), "An attitudinal model of technology-based selfservice: moderating effects of consumer traits and situational factors", Journal of the Academy of Marketing Science, Vol. 30 No. 3, pp. 184201. https://doi.org/10.1177/0092070302303001

19. Agarwal, R. and Prasad, J. (1998), "A conceptual and operational definition of personal innovativeness in the domain of information technology", Information Systems Research, Vol. 9 No. 2, pp. 204-15.

20. Mick, D.G. and Fournier, S. (1998), "Paradoxes of technology: consumer cognizance, emotions, and coping strategies", Journal of Consumer Research, Vol. 25, pp. 123-47. https://doi.org/10.1086/209531

21. Davis, F.D., Bagozzi, R.P. and Warshau, P.R. (1989), "User acceptance of computer technology: a comparison of two theoretical models", Management Science, Vol. 35 No. 8, pp. 982-1003.

22. Parasuraman, A. (2000), "Technology readiness index (TRI): a multiple-item scale to measure readiness to embrace new technology", Journal of Service Research, Vol. 2 No. 4, pp. 307-20.

23. Parasuraman, A. and Colby, C.L. (2001), Techno-teady Marketing, The Free Press, New York, NY.

24. Lin, C.H., Shih, H.Y. and Sher, P. (2007), "Integrating technology readiness into technology acceptance: the TRAM model", Psychology \& Marketing, Vol. 24 No. 7, pp. 641-57.

https://doi.org/10.1002/mar.20177

25. Massey, A.P., Khatri, V. and Mitzi, M.M. (2007), "Usability of online services: the role of technology readiness and context", Decision Sciences, Vol. 38 No. 2, pp. 277-308.

26. Liljander, V., Gillberg, F., Gummerus, J. and van Riel, A. (2006), "Technology readiness and the evaluation and adoption of self-service technologies", Journal of Retailing and Consumer Services, Vol. 13 No. 3, pp. 177-91.

27. Walczuch, R., Lemmink, J. and Streukens, S. (2007), "The effect of service employees' technology readiness on technology acceptance", Information \& Management, Vol. 44, pp. 20615. https://doi.org/10.1016/j.im.2006.12.005

28. Lin, J.S.C. and Hsieh, P.L. (2005), "The influence of technology readiness on satisfaction and behavioral intentions toward self-service technologies", Computers in Human Behavior, Vol. 23, pp. 1597-615. https://doi.org/10.1016/j.chb.2005.07.006

29. Yi, Y., Wu, Z. and Tung, L.L. (2006), "How individual differences influence technology usage behavior? Toward an integrated framework", Journal of Computer Information Systems, Vol. 46 No. 2, pp. 52-63.

30. Fornell, C., and Larcker, D. F. Evaluating structural equation models with unobservable variables and measurement error. Journal of Marketing Research, 18, 1, 1981, 39-50.

31. U. Rahardja, A. Moeins, \& N. Lutfiani, "Leadership, competency, working motivation and performance of high private education lecturer with institution accreditation B: Area kopertis IV Banten province", Man in India, 97(24), 179-192, 2017.

32. U. Rahardja, T. Hariguna, \& Q. Aini, "Understanding the Impact of Determinants in Game Learning Acceptance: An Empirical Study", International Journal of Education and Practice, 7(3), 136-145, 2019. http://doi.org/10.18488/journal.61.2019.73.136.1 45

33. T. Hariguna, \& Berlilana, "Understanding of Antecedents to Achieve Customer Trust and Customer Intention to Purchase E-Commerce in 
Husni Teja Sukmana et al., International Journal of Advanced Trends in Computer Science and Engineering, 8(1.5), 2019, 249 - 257

Social Media, an Empirical Assessment", International Journal of Electrical and Computer Engineering, 7(3), 1240-1245, 2017. http://doi.org/10.11591/ijece.v7i3.pp1240-1245

34. M. June, S. E. L. Cheng, L. G. B. Lim, and J. H. C. Ramos, "Development of an Optimized Greenhouse Automation System," Int. J. Adv. Trends Comput. Sci. Eng., vol. 8, no. 3, pp. 531537, 2019. https://doi.org/10.30534/ijatcse/2019/30832019

35. M. Thomas, I. Journal, M. Thomas, and V. S. Chooralil, "Security and Privacy via Optimised Blockchain," Int. J. Adv. Trends Comput. Sci. Eng., vol. 8, no. 3, pp. 415-418, 2019.

https://doi.org/10.30534/ijatcse/2019/14832019 